\title{
From Radical Progressivism to Authoritarianism
}

By Barry L. Clark, December 2019

$\mathrm{M}$ any Americans, and perhaps Westerners for that matter, look around at the world and the culture with confusion. Much has changed since WWII, a lot more since the 1960s. Those changes pale in comparison to the turbulence and transformation in the last thirty years. The changes in the cultural landscape in the 2000s would have been at best laughable notions in 1950. Like frogs in a boiling pot, few really recognize the change for what it is, transformative and revolutionary. Rather than upfront, comprehensive and collected into one easily identifiable category, the cultural revolution has been incremental and progressively elaborating in its manifestation. It is perhaps that fact that has kept most Americans blind to what was truly occurring.

To be certain, segments within the populace have taken exception to pieces and parts of the revolution as it unfolded, usually in terms of what they perceived as singular, stand-alone issues. Some opposed abortion, others fought for gun rights, while others fought for the family or for morality in society. At the same time various camps that fought for one issue ignored others, these were separate issues, not connected components to them. Some might support gun rights but shrug their shoulders over family issues, etc. All the while failing to realize that all the issues the progressive left has championed over the last four decades have been interconnected to them, it was all part of a larger fight. To many that held to some distant notion of what America was founded as, what rights mean, what right and wrong are and who we ought to be, the understanding that there was a comprehensive fight going on never occurred to them.

\section{To the Radical, this is Revolution}

The same cannot be said of the left, those that adhere to a radical, revolutionary progressive ideology. This is certainly not a homogenous group, all following lock-step to the orders of a behind the scenes mastermind. There is no center of gravity of this movement, it is an ideology and as such, it exists beyond mere personality and singular organizations. That being said, there are guidepost that they all heed, sacred texts if you will that shape their actions. Saul Alinksy's Rules for Radicals, published in 1971 at the height of the counter-culture movement is one such document. Modified versions of Alinsky's Rules are used by Justice Democrats, Brand New Congress, The Young

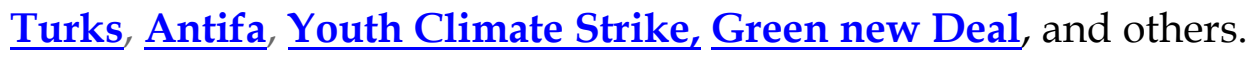


Alinsky made it clear that radical change was a power structure and not merely a reformation of the status quo. He advised that "[a]ny revolutionary change must be preceded by a passive, affirmative, non-challenging attitude toward change among the mass of our people." (Alinsky 1971, p.xix) Traditional-minded Americans have failed to understand this as a revolution. It is this failure to fully grasp what has been occurring is the prime reason that the progressives have been so successful. Most Americans thought nothing of monuments being torn down, these were just granite things and people said it hurt their feelings. To oppose abortion or homosexual marriage might make one look backward and hateful, let the Bible beaters fight that. A person that does not own guns may not see the reason to oppose gun control. There are just too many shootings, so they remain silent or even join the progressive cause. None of those people realize that each of those issues fed into the progressive agenda. Some were easy wins that built momentum, others attacked the foundational philosophical foundation of the old order. Each issue, and each victory built toward greater progressive victories. The radicals were aligned by an ideology that focused them, traditional America was confused and divided.

\section{Decline and Failure of Classical Liberalism}

This change did not begin in the 1960s with the counterculture. As Hans Hermann Hoppe points out in Democracy, The God that Failed, "classical liberalism has been in decline for more than a century. The second half of the nineteenth century in the US, as well as in Western Europe, public affairs have increasingly been shaped instead, by socialist ideas" (Hoppe 2018, p. 221) In fact, classical liberalism itself began to fail soon after it was first theorized during the Enlightenment. Once classical liberal theorist began to abandon notions of universal truth the philosophy began to divide into error and ideology. (B. Clark 2019) However, this is not to say that there were no good ideas that arose from Enlightenment. Ideas that in their original form aligned with truths men had come to accept prior we good notions. At the time of the founding of the United States, enough of the prime tenets of what was good of classical liberalism were written into the form of government to produce something unseen in human history.

What then might explain the decline and failure of classical liberalism? If forced to provide one word that signifies the core of the battle it is 'truth'.

\section{Truth}

Abandonment of truth polluted and perverted classical liberalism and it is truth itself that radical progressives now assault. All of the issues and singular battles are part of a revolution and new metanarrative against truth. In fact, each of the issues that have 
comprised the cultural war in the last 40 years have been battles of truth. It was never about marriage, or monuments or words, not to the progressives at least. Each one of those fights was an assault on an accepted truth. By breaking down the narratives of truth in civilization they gained the power to assault ultimate truths. In The Philosophy of Commonsense, I argue that truth, universal truth, must exist. I begin with the premise that the same thing cannot be affirmed and denied at the same time. "Anyone that proclaims that no truth exists is, in fact, making an argument for the existence of truth, an argument that relies upon a statement that no truth exists in appealing to truth. It is impossible to honestly argue for the existence of no truth by stating that there must be a truth that no truth exists." (B. L. Clark 2019, p.16)

It is impossible to really and honestly attack the notion that any truth exists. Besides, the radical progressives do believe that they hold to some truth, even if they cannot universally define it. Thus, they have focused their attacks on the truths that hold up the system they want to destroy and replace.

\section{Permanent Things as Truths}

Most of the progressive attacks have centered on permanent things or on elements that directly support permanent things. Permanent things are as Russell Kirk described,

"[T]hose elements in the human condition that give us our nature, without which we are as the beasts that perish. They work upon us all in the sense that both they and we are bound up in that continuity of belief and institution called the great mysterious incorporation of the human race." (Kirk 1969)

In a significant way, the big story of the Bible teaches us that throughout time and various revelations, certain things remain important, permanent. These lessens began in Genesis. God created man, life, being and existence (Genesis 1:26) and then a relationship to man with order and law (Genesis 2:18), then the Family (Genesis 2:24), wages of sin (Genesis 3:819), and finally the concepts of social order, civil law, and society. (beginning in Genesis 4:8) *One might argue that life is not permanent, it ends, and our mortal bodies die. True, but our being and existence is, guaranteed through the second permanent thing, our relationship with God (B L Clark 2019, p.16)

These concepts have been central to Western Civilization for two millennia. Without these permanent things, Western Civilization ceases to be the West, a point not lost on the progressive revolutionaries. Their attacks on these permanent things, or on items that support permanent things include the following: 
- Abortion: an attack on the Christian metaphysical notion of life as a permanent thing - a truth accepted by the West for centuries; it was not liberty to choose as the slogans claimed, it was license to ignore truth.

- Historic monuments: Removing monuments and renaming institutions was an attack on the vestiges of a view of history that was contrary to the progressive/socialist narrative; not a real attempt to heal racial division, it increased such.

- Gun control: is about denying humans natural rights to property, life, and liberty, unarmed people are incapable of defending those rights from their neighbors and from government. Without an ability to defend life, liberty, and property all other permanent things are imperiled; it was not about stopping crime or shootings.

- Homosexual marriage: an attack on the foundational element of civilization, the family, the third permanent thing as well as on the notion that sin itself exists. It was not about love or fairness and only concerned with 'liberty' insofar as that meant license to ignore universal truths.

- Transgenderism: an assault on the very core of Western ideas of realism, existence and of the Christian metaphysical reality that gave rise to those ideas. Transgenderism is a denial of natural, knowable and observable truths and therefore perhaps the boldest attack on truth yet.

- Critical Theory: in all forms but particularly that of Critical Race Theory, Critical Gender Theory and other variations are an assault on social order, the fifth permanent thing. These theories have come to dominate academia and the ideology of the left. They create racism and genderism as forms of division and hate. They elevate entire classes to hapless victims and others to wanton oppressors, giving de facto moral superiority to one and stripping the other of humanity.

- The subtle but persistent War on Masculinity is an assault on the family and of truths the West has accepted concerning gender roles for centuries.

- Language orthodoxy: In Orwellian fashion, the domination of the language, or as Daryl McCann argues "the Sixties Revolution has gone the way of the French Revolution, the Russian Revolution, the Chinese Revolution and every other left- 
wing revolution that comes to mind. The radicalism of yesteryear somehow turned into PC orthodoxy or what we might call Correctism." (McCann 2019)

Many Americans over the last forty years looked at the issues above as completely unrelated, having little to nothing to do with each other. Most never stopped to wonder why the same groups, with the same tactics and methods, were on the side of change in each case. If ordinary Americans look around now in confusion as to how everything has so fundamentally changed it is because they failed to realize all of this was always a battle about truth.

This difference might best be described in a simple question; does a person believe ethics exist because truth exists, or do they believe truth exist because ethics exist? There is a magnitude of difference between the two answers to that question. In the former, ethics are universal and guided by both knowable and revealed truths. In the second, man is left to continually wonder, argue and eventually just acquiesce to the majority view of what is true and correct just for the moment.

\section{An Ideology, Not a Conspiracy}

At times of confusion, it is often easier to look for a singular target to focus our angst and fear upon. It is a lot easier to look around at our world and conclude that all of the changes are part of a conspiracy, controlled by some secret cabal. Once one looks at the historical progression, how one event enabled progress to follow and how there seems to be a flow and a theme to it all the simple answer might seem that someone or a group must be at the center of it all.

Unfortunately, that is the very nature of an ideology. Once diffused into a population it takes on a life of its own, always centering adherents back toward its core loci. This does not mean nobody has ever conspired to advance progressive issues, people conspire all the time. It does not mean that some groups have been more successful than others in taking a lead to shape the intellectual positions of the ideology. It does not mean that there have not been significant individuals that represent the public face of the ideology. However, as an ideology, once diffused, it can survive in the wild without any of the groups or people you might name as famous progressive advocates. If those were removed others would replace them. An ideology cannot be killed by eliminating specific people or organizations, a lesson the US failed to learn in the middle east after almost 20 years of war.

\section{History of the Revolution}


The following is not a mere history lesson, nor just a presentation of a view of history, it is the path that government in America followed from the notions of classical liberalism written into the Declaration of Independence and fought for in the American Revolution to the current state of cultural, legal and governmental affairs. One cannot separate the path that got us here from the position we now occupy. It has been a series of events, a slow progression and a cascading failure.

Hoppe in Democracy noted that accepting the moral status of government was the initial cause of classical liberalism going astray.

"Liberalism's erroneous acceptance of the institution of government as consistent with the basic liberal principles of self-ownership, original appropriation/property/ and contract, consequently led to its own destruction.

First and foremost, it follows from the initial error concerning the moral status of government that the liberal solution to the eternal human problem of security-a constitutionally limited government-is a contradictory praxeologically impossible ideal. Contrary to the original liberal intent of safeguarding liberty and property, every minimal government has the inherent tendency to become a maximal government. " (Hoppe 2018, p. 229)

In the American Republic, this began before the Republic itself was born in 1788. The Federalist, centralist would have been a more appropriate term, held ideas of a more powerful, central government that might provide the most public good. Men like Alexander Hamilton, James Madison and John Jay were the most vocal of this original group but the ideology grew and became one of the opposing points of view that led to the American Civil War. The anti-federalists, more aptly called federalists because of their view of a republic with a central government possessing only certain delegated powers, included Thomas Jefferson, Samuel Adams, and Patrick Henry. This view came to be called sectionalism, with its most famous supporter and advocate being John C. Calhoun. From 1788 until 1850 the issue was one of disagreement and debate, tempered by the existence of checks and balances placed within the Constitution that ensured neither side could assert dominance.

Much like the vast gulf between how one views truth, the difference in viewpoint between a republican and central form of government is vast, too vast to exist side-byside for long without conflict. To a republican (Anti-Federalist), government was inherently oppressive and should be restrained as much as possible and this restraint was best achieved locally. To the centralist (Federalist), government was a force that could perform good and was best centralized to make it more effective. These are 
diametrically opposed viewpoints. Civil war was inevitable on the American continent so long as these two views existed alongside each other with the relative power to check and confound the other.

By 1865, as an inept professor of mine once told me, the issue was settled on the battlefield. The meaning of the original compact, of the Tenth Amendment and of sovereignty were redefined. In 1867 the initial revolution from one view of original intent to another was completed with the Fourteenth Amendment. As George P. Fletcher points out in Our Secret Constitution: How Lincoln Redefined American Democracy we essentially had a second constitution after 1867 based upon "organic nationhood, equality of all persons, and popular democracy" concepts different and opposed to those of our first constitution which promulgated "peoplehood as a voluntary association, individual freedom, and republicanism". (Fletcher 2003)

This revolution is not without controversy. Leave aside the centralists narrative that three years into the war it was suddenly about ending slavery, a feat that surely could have been done in a more economical and less destructive way than a war costing millions of dollars and over 600,000 lives. This was not their narrative at the beginning of hostilities, then it was about power and control and the preservation of their centralists worldview. However, it is the actions after the war with the irregular circumstances of implementation of the 14th Amendment that were most transformative. As Forrest McDonald Concluded in Was the 14th Amendment Constitutionally Adopted?, "clearly, then, the Fourteenth Amendment was never constitutionally ratified." (McDonald 2018, p.59) McDonald makes a compelling case, that the procedures used to force ratification were not only irregular but unconstitutional. However, this amendment was necessary. The opposing voice to centralism had been silenced, disposed of political power and impoverished but the mechanism of original intent was still in place. The 14th Amendment ensured that the revolutionary change of 1861-1867 would stick.

The progressive movement itself was possible only because of the events of 1861-1867. Paul D. Moreno states in The American State from the Civil War to the New Deal that progressivism was initially a shift toward expanding government power and away from Constitutional limits. (Moreno 2013) Prohibition, Federal government welfare, a central bank, the federal income tax, and even eugenics all owe their existence on the American continent to that revolutionary change. Each of those programs and movements began with good ideas, with high notions of what ethics were and a faith in government as a moral entity. Each in its own way failed, prohibition created more crime, welfare more poverty, the income tax created more intrusive government and denied people their rights to their own property. Finally, eugenics, born in America and championed by 
people like Margaret Sanger, manifested itself fully in Germany and the Holocaust. (Conley 2017) All these programs and ideas, progressive ideas, resulted in less freedom and all failed to ultimately achieve the goals the original proponents championed. That is, as Hoppe pointed out, the key fallacy of placing moral hope in government.

This is of course not to imply that humans ought never 'progress' or improve. To attach such a notion to me would be to build a strawman. The problem with progressives since the mid 19th-century is their failure to understand that government is a necessary evil, not a moral agent. As much evil and suffering as good will always come from any and every law written with good intentions. In the 19th-Century progressives did not understand this. In the late 20th and early 21st centuries they understand it full well but have come to view ethics through the lens of a power struggle; if the other side suffers in order to do what they perceive is good, so be it. This is how radically far the progressive movement has come and thus why progressivism, as adhered to by radical revolutionaries in our era, will ultimately lead to authoritarianism.

\section{Radical Tactics}

Understanding the history, those events that have built upon an ideology and put teeth at the disposal of progressives of our time is important, yet this does not explain the tremendous success of the ideology over the last 40 years.

Saul Alinsky's Rules for Radicals does help explain it. Alinsky drew on lessons from Marxist tactics while trying to separate the counter-culture and progressive revolution in America from that term. Rules has been and is being used by various progressive groups since its publication in 1971. Many have modified the tactics to fit their own personalities and approaches, but the basic principles remain unchanged.

Alinsky spends the first short chapter of his book discussing morality but quickly descends into a worldview that obviously believes ethics determine truth.

He states:

Means-and-ends moralists, constantly obsessed with the ethics of the means used by the Have-nots against the Haves, should search themselves as to their real political position. They are passive-but allies- of the Haves they are the ones Jauques Maritain referred to in his statement, "The fear of soiling ourselves by entering the context of history is not but a way of escaping virtue." (Alinsky 1971, pp. 25-26) 
Alinsky is quoting Maritain's most Machiavellian thoughts, perhaps out of context because Maritain stressed an acceptance of ultimate truth as the source of ethics. (Sweetman 1999) By choosing and misquoting Maritain, Alinsky attempts to add philosophical and theological credence to a set of ethical rules that allow and encourage progressives to do some evil in order to accomplish some good, good being defined by progressives. By avoiding Machiavelli, Alinsky steers clear of what many in the counter-culture would have seen as an icon of the oppressive state.

The point, however, as Alinsky makes clear from the outset, is that right and wrong do not matter, winning does. As he says, "the third rule of the ethics of means and ends is that in the end justifies almost any means." (Alinsky 1971, p.29) Taken plainly, one can infer already how progressivism ultimately ends in authoritarianism, just as socialist ideas and inflamed passions in the French Revolution ended in tyranny.

Speaking of Lincoln's illegal, and Alinsky admits it as such, suspension of habeas corpus he states, "he who would be critical of the ethics of Lincoln's reversal of positions have a strangely unreal picture of a static unchanging world, where one remains firm and committed to certain so-called principles." (Alinsky 1971, p. 31) Compare that to a contemporary of Lincoln's, Alexander Stephens who said: "times change and men often with them, but principles never!" (A. H. Stephens 1868) Alinsky admits here a disdain for principles, principles derive from truth, thus is illuminated to full objective of the progressive movement, the elimination of universal truth.

An axiom of histography is that the victor often writes the history of the war. The judgment of future generations is generally shaped by those histories. Alinsky acknowledged this when he advised, "the seventh rule of the ethics of means and ends is generally, success or failure is a mighty determinant of ethics" (Alinsky 1971, p.34) If you win, who is to judge your actions as right or wrong he is saying.

He does not forgo the need for the air of morality, to appear to hold the moral high ground, "the tenth, rule of the ethics of means and ends is that you do what you can and clothe it in moral arguments." (Alinsky 1971, p. 36) We can readily observe this in the current progressive movement. All their causes center on ill-defined notions of fairness and justice and appeal to emotions. They turn hatred of an entire race, 'whiteness', into an appeal for action, anger, and vitriol toward an entire class, the rich, into calls for equity, using the most dangerous of human emotions and passions clothed in a false morality to advocate their cause. Equity, justice, fairness are their battle cries, just as Alinsky suggested, "the eleventh rule of the ethics of means and ends is that goals must be phrased in general terms like "Liberty, equality, fraternity", "Of the Common 
Welfare, "Pursuit of Happiness" or "Bread and Peace!' Whitman put it: "The goal once named cannot be countermanded." (Alinsky 1971, p. 45)

Alinsky was not above targeting people individually, he even suggested it. He provided an example of a new school board chairman that opposed his group's proposals. By the account of Alinsky's follows this was a good church-going, family man with no apparent vices. But that did not matter, he was in the opposition and according to Alinsky, there can be no black and white on an issue, everyone is for or they are opposed, there is no room for compromise. Alinsky and his group used ridicule, isolation, polarization and 'freezing', think modern canceling and doxing, on this man. He advised, "ridicule is man's most potent weapon it is almost impossible to counterattack ridicule" and 'if you push a negative hard and deep enough it will break through into its counterside" and finally, "pick the target, freeze it, personalize it, and polarize it." (Alinsky 1971, pp. 128-130)

In terms of how to find issues to stir the mob toward action, Alinsky states, "in the beginning the organizer's first job is to create the issues or problems" and that "the major premise for tactics is the development of operations that will maintain a constant pressure upon the opposition." He also demonstrated little confidence $\mathrm{n}$ the masses to actually understand the issues or know what they really want. It was the organizers job to help them figure that out. Lastly, he advised that the mobs tend to get bored of an issue and organizer's need to continually find new issues to keep everyone engaged. (Alinsky 1971)

We have seen and continue to see almost all of these tactics in use by the progressive revolutionaries. Consider for a moment, if you were a progressive organizer in the late 1980s, an adherent to the ideology described above, a person that sought revolutionary change. How would you accomplish that? You could not launch a frontal assault on the family and marriage from the start. As Alinsky said, "any revolutionary change must be preceded by passive, affirmative, non-challenging attitude toward change among the mass of our people."(Alinsky 1971, p. xix) It would take time to get most of the population into at least a neutral position on gay marriage. In the meanwhile, you have to keep the momentum going, you have to keep and expand your base of support. You would realize that a traditional ally of your cause, black Americans, have historically been more opposed and less accepting to homosexuality than the general population. (Lewis 2003) How can you eventually use your coalition to address all the issues on your plate if you risk losing an important constituency? You pick battles that are easy to win early and that speak directly to that constituency. You bring racism back to the fore and create a racial divide. Beginning in the 1990s the issue was removing the 'battle flag' and proximations of that image from state flags. In the 2000s it was mobilizing 
progressives to support Black Lives Matter and then an assault on monuments and statues. It manifested into an attack on privilege and whiteness, equating unrepentant and non-woke whites as morally inferior and unworthy of being heard or seen. It gave birth to an entire concept in social science known as Critical Race Theory, derived directly from Marxism. Those were all easy wins, they kept the coalition together and cemented much black support, support needed later.

Through those three decades, the issues of gun-control, religious tolerance (of Christianity) and homosexuality were not abandoned, they were just not foremost in the progressive agenda. Media and the entertainment industry did most of the heavy lifting, moving enough of the apathetic, low-information, non-critical thinking middle toward neutrality or acceptance. A logical person, in the position described above in the late 1980s, would have likely operated exactly as it all played out, Alinsky wrote the Rules and they work.

\section{There is no Neutral Ground}

There remains an illusion in domestic politics that a center exists, that a person can be thoughtful, diligent, compassionate and undecided. Perhaps in terms of parties, there is often a decision to be made, as in to vote at all. To be certain many Republicans are neoliberals or neoconservatives. However, between progressive or not, there can no longer be a place for a truly undecided. A person either believes ethics exist because truth exists, or do they believe truth exist because ethics exist. If they fail to recognize the question, if they do not see the vast philosophical difference of metaphysical opinion concerning truth, then, of course, they are undecided, because they are unaware of the fundamental question at play. America is more divided than at any point since 1850, precisely because of the vast philosophical and metaphysical differences in the two camps. (Clark 2018)

The progressive seeks only a non-challenging attitude from the non-woke 'undecideds' of society. They do not need their support per se, they simply must gain their apathy.

Using the example of the Bolshevik take over after the Russian Revolution Alinsky notes,

'The task of the Bolsheviks is to overthrow the Imperialist Government. But this government rests upon the support of the Social Revolutionaries and Mensheviks, who in turn are supported in the trustfulness of the masses of people. We are in the minority-In these circumstances, there can be no talk of 
violence on our side' The essence of Lenin's speeches during this period was

'They have the guns and therefore we are for peace and for reformation through

the ballot. When we have the guns then it will be through the bullet.' And it

was. (Alinsky 1971, p. 37)

The progressive, like his Marxist master and teacher, is a patient and cunning creature, willing to take small game, steal resources when his adversary is not looking and bide his time until the mass of the population either does not notice or care about his schemes, it is then, once power is gained that he can show the full fright of his teeth and claws.

The 'undecided', unengaged, un-informed masses are separated only by degrees from the pimple-faced kid that dons a black bandana and marches for Antifa. Each does his part, in his own way, for the progressive cause.

\section{Implications}

Many Americans still hold to a belief that permanent things should be preserved. Many of those have also come to hold dear pieces and parts of postmodern progressive ideology that often make it difficult to understand what preservation means. Fewer still retain faith and allegiance to one of the permanent things of Western civilization, Christianity. Of those that profess to believe, many are confused by strange doctrines that derive from false ideology. Americans do not even have a political party they can go to the polls to vote for that is clearly on the side of preserving permanent things. Democratic socialist progressivism and Republican neoconservatism are two sides to the same ideological coin. Without a party, an organized and untainted religious institution and a rally cry, traditionalists seem to have no hope of reversing the cultural decline and ideological ascendancy of progressivism. It is too far entrenched, in churches, academia, and the political system. Whether this is the ultimate outcome and the last vestiges of traditionalism and conservatism are to go extinct, remains to be seen and beyond the scope here. However, without a significant change, it seems certain.

\section{Is Progressivism Really Socialism?}

William English Walling in Progressivism--and After certainly conflated socialism and progressivism to a large degree. He termed progressive reforms as "useful but temporary makeshifts" to the socialist plan. (Walling 1914) Walling among other things was a co-founder of the NAACP, a member of the socialist party and a vocal supporter and apologist for Soviet communism. John D. Stephens in The Transition from Capitalism to Socialism states that Western capitalist democracies moving to become welfare states through progressive policies was a realization of Marx' theory that when the conditions 
were correct a capitalist society would transform into a socialist one. (J. D. Stephens 1979) Already in the US, a third of millennials polled advocate socialist programs. (Langlois 2019) So it seems that in the mind of socialist progressivism is a form of socialism, and in the mind of many in our culture that hold to progressive ideology socialism looks pretty good. If they are not the same, they are close cousins. We can conclude therefore that progressivism must necessarily lead to socialism.

\section{Must Socialism Lead to Authoritarianism?}

Despite the overall denial in general academia and propensity to label all authoritarianism as a right-wing phenomenon, Sabrina de Regt points out in Left-wing Authoritarianism is not a Myth, but a Worrisome Reality that not only does it occur on the left but that fascism and communism have much more in common that most scholars care to admit. (Regt 2011) Henry A. Giroux, a man of solid Marxist ideological credentials, argues out in Terror of Neoliberalism that the US has entered a dark stage of cronyism, what he terms neoliberalism and most would recognize as neoconservatism. He concludes that this ideology, really just the right side of the left-leaning coin, as progressivism and neoliberalism and neoconservatism all derive from flawed version of classical liberalism, has destroyed the foundations of the capitalist economy, controls the media and the culture and has all access to government and power. (Giroux 2018) The conclusions of both de Regt and Giroux agree with Hoppes theory in Democracy, The God that Failed, in that classical liberalism, polluted near the root, generated ideologies that could not long stand without resorting to authoritarianism. In the US, all the Democratic party and most of the Republican party, the neoconservative branch, have aided and assisted in putting in place the mechanisms by which authoritarianism might manifest itself in America.

As a reaction to or fulfillment of progressive ideology, authoritarianism has the real potential to become reality via three paths.

First, progressive socialism itself, coupled with high-minded but impossible ideas would certainly lead to authoritarianism. Socialism combined with an ideology that seeks to create equality and justice where they do not exist in nature, by necessity must create new laws to achieve those goals. When initial efforts fail, and they must because it is impossible to make all men equal unless you strip all men of all abilities and possessions, the progressive must create more laws and programs, more taxes and more redistribution of wealth. Under such circumstances, by the very nature of its unrealistic goals and the collective power of socialism, progressivism must by necessity end in greater authoritarianism. 
Second, neoliberalism/neoconservatism could retain power and expand its infrastructure so as to become immune to populist ideations for the right or left. This sort of status quo creeping authoritarianism would be invisible to most Americans, imperceptible, as civil liberties were further eroded, surveillance increased, and police powers expanded incrementally as they have over the last decades.

Lastly, a counter-reaction to the progressive social justice movement could theoretically utilize the same disregard for constitutional limitations and appetite for expanded government power to enact some form of fascism as a counter-cultural revolution. This is perhaps the favorite boogeyman of the left, often incorrectly conflated with neoconservatism and their grasps at power. This is the least likely path to authoritarianism. Traditionalists and real conservatives are simply not that organized and besides, real conservatives believe in Constitutional limitations and principles; concepts incongruent with totalitarianism.

Power corrupts and governmental power is no exception. In US history we can clearly observe the central government moving from a position of first among states to an entity that would allow 600,000 citizens to die to ensure its continued existence. We have seen the rise of faceless, distant agencies that control much of what we do. We understand, intuitively and by observation, how government grows. We can infer what greater centralization and more power and control will mean. No concept that was once sacrosanct - free speech, religious liberty, self-defense, private property, parental rights and even life itself - is not guaranteed in such a scenario.

1984 may not be a reality in anyone's life that perchance reads this, but totalitarian autocracies begin somehow, and our path seems a sufficient start. We can only observe the path the ideology has taken thus far and the ethics of its adherents coupled with the propensity of the mob toward violence to deduce the possible outcomes.
About
This monograph is part of the Fourth Turning Clash of Inter-Civilization Cultures project. DOI: 10.13140/RG.2.2.32977.28008 (B. Clark 2019)
Authoritarianism : Generational Theory $:$ Gun Control $: \underline{\text { Retrenchment }}:$ Cultural War $:$ Politics $:$ Faith and Reason
Barry L. Clark is a Southerner, father, husband, Christian and a retired Army field grade officer. Author of five books and of several papers and articles on ethics, culture, history, geopolitics and military affairs.
Twitter: @onlyBarryLClark Web: http://barryclark.info/
Author of:

- Retrenchment: Christian Defense of Permanent Things 
- The Philosophy of Commonsense: A Cultural War Primer

- A Commonsense Case for Christianity

- Things You Are Not Supposed to Know About a Military Career

- The Annotated Secessionist Papers, Second Edition

\section{Copyright}

Barry L. Clark All Rights Reserved, Copyright@ 2019

\section{Bibliography}

Alinsky, S. 2010. Rules for Radicals: A Pragmatic Primer for Realistic Radicals. Vintage. Knopf Doubleday Publishing Group. https://books.google.com/books?id=VIHOUbZ8qU4C.

Barry Clark. 2018. "America's Great Cultural and Political Divide." The Calhoun Review, 5.

Clark, B L. 2019. Retrenchment: Christian Defense of Permanent Things. https://books.google.com/books?id=0HPDDwAAQBAJ.

Clark, B L, B L Clark, B McCandliss, M Peirce, W E Block, T E Woods, K L Clauson, et al. 2018. The Annotated Secessionist Papers: Second Edition. The Calhoun Institute. https://books.google.com/books?id=-jVhDwAAQBAJ.

Clark, Barry. 2019. "Fourth Turning Clash of Inter-Civilization Cultures Thesis." https://doi.org/10.13140/RG.2.2.32977.28008.

Clark, Barry L. 2019. "The Philosophy of Commonsense : A Cultural War Primer." https://books.google.com/books/about?id=CK6-DwAAQBAJ.

Conley, John J. 2017. "Margaret Sanger Was a Eugenicist. Why Are We Still Celebrating Her?" 2017. https://www.americamagazine.org/politics-society/2017/11/27/margaret-sanger-was-eugenicistwhy-are-we-still-celebrating-her.

Fletcher, G P. 2003. Our Secret Constitution: How Lincoln Redefined American Democracy. Oxford University Press. https://books.google.com/books?id=P5VSyor50fIC.

Giroux, H A. 2018. Terror of Neoliberalism: Authoritarianism and the Eclipse of Democracy. Taylor \& Francis. https://books.google.com/books?id=x-pTDwAAQBAJ.

Hoppe, H H. 2018. Democracy -- The God That Failed: The Economics and Politics of Monarchy, Democracy and Natural Order. Perspectives on Democratic Practice. Taylor \& Francis. https://books.google.com/books?id=bvdKDwAAQBAJ.

Kirk, R. 1969. Enemies of the Permanent Things: Observations of Abnormality in Literature and Politics. Arlington House. https://books.google.com/books?id=xLCBAAAAMAAJ.

Langlois, Shawn. 2019. "More than a Third of Millennials Polled Approve of Communism." Market Watch. 2019. https://www.marketwatch.com/story/for-millennials-socialism-and-communism-arehot-capitalism-is-not-2019-10-28.

LEWIS, GREGORY B. 2003. "Black-White Differences in Attitudes toward Homosexuality and Gay Rights*." Public Opinion Quarterly 67 (1): 59-78. https://doi.org/10.1086/346009.

McCann, Daryl. 2019. "How the Left Turned Free Speech into Hate Speech." Quadrant 63 (1/2).

Moreno, P D. 2013. The American State from the Civil War to the New Deal: The Twilight of Constitutionalism and the Triumph of Progressivism. The American State from the Civil War to the New Deal: The Twilight of Constitutionalism and the Triumph of Progressivism. Cambridge University Press. https://books.google.com/books?id=33uupwdgNLgC.

Regt, Sabrina. 2011. "Left-Wing Authoritarianism Is Not a Myth, but a Worrisome Reality. Evidence from 
13 Eastern European Countries." Communist and Post Communist Studies, no. 44: 299-108.

https://lesacreduprintemps19.files.wordpress.com/2013/07/left-wing-authoritarianism-is-not-amyth-but-a-worrisome-reality-evidence-from-13-eastern-european-countries.pdf.

Stephens, A H. 1868. A Constitutional View of the Late War Between the States: Its Causes, Character, Conduct, and Results; Presented in a Series of Colloquies at Liberty Hall. A Constitutional View of the Late War Between the States. National Publishing Company.

https://books.google.com/books?id=mggTAAAAYAAJ.

Stephens, J D. 1979. The Transition from Capitalism to Socialism. Palgrave Macmillan UK. https://books.google.com/books?id=aPSxCwAAQBAJ.

Sweetman, B. 1999. The Failure of Modernism: The Cartesian Legacy and Contemporary Pluralism. American Maritain Association Publications. American Maritain Association. https://books.google.com/books?id=1is2DSsO4WwC.

Walling, W E. 1914. Progressivism--and After. Library of American Civilization. Macmillan Company. https://books.google.com/books?id=bo8pAAAAYAAJ. 